\title{
Personal Taxation, Portfolio Choice, and the Effect of the Corporation Income Tax
}

\section{Martin S. Feldstein}

Harvard Unizersity and the National Bureau of Economic Research

\section{Joel Slemrod}

Uninersity of Minnesola and the National Bureau of Economic Research

Extending the traditional treatment of the corporate tax to an economy with a progressive personal tax fundamentally changes the analysis. While the corporate tax system (CTS) does increase the total tax rate on corporate source income for some investors, the exclusion of retained earnings implies that the CTS lowers the tax rate for high-income investors. Analyzing such an economy requires replacing the traditional "equal-yield" equilibrium condition with a more general portfolio balance model. In this model, introducing a CTS can actually increase the corporate share of the capital stock even though the relative tax rate on colporate income rises.

The current theory of public finance views the corporate income tax as an extra tax on income in the corporate sector. ${ }^{1}$ This implies that the corporate income tax penalizes activity in the corporate sector. As a result, the corporate sector uses a smaller fraction of the nation's capital stock than it would use if corporations were taxed like partnerships.

This paper is part of the National Bureau of Economic Research's program of research in Business Taxation and Finance. The views expressed here are the authors' and should not be attributed to any institution. We are grateful to the referee for his very helpful comments on the earlier version of this paper.

1 Harberger (1962) is the best and most widely known statement of this theory. The more recent analyses by Shoven and Whalley (1972) and Shoven (1976) also start from this premise. 
This widely accepted conclusion rests on the simplifying assumption that all investors have the same personal tax rate. In fact, of course, personal tax rates vary greatly. Some investors pay no personal income tax while others pay tax rates of up to 70 percent. The present paper shows that this variation in the personal tax rate may be very important for understanding the allocative effect of the corporate income tax.

Recognizing differences in personal income tax rates significantly changes the analytic structure of the problem and implies that our corporate income tax system could actually increase the fraction of the nation's capital stock that is employed in the corporate sector. The basic reason is that, under the corporate income tax system, retained earnings are not subject to the personal income tax. While dividends are taxed twice, retained earnings are taxed only at the corporate income tax rate, which is lower than the personal rate for many shareholders. Although personal tax may eventually be paid on the increase in share value that results from the retained earnings, this tax would be at the lower capital gain rate and could be postponed for a long time. For those high-income investors whose marginal rates of personal income tax are significantly greater than the corporate tax rate, the corporate income tax shelters retained earnings from the higher rate of personal income tax. Thus, although the corporate income tax system represents an increase in the total tax on corporate sector income (i.e., on the pretax profits of corporations) for lower-income and middle-income investors, for many investors with high tax rates the corporate tax system actually lowers the effective tax rate on corporate-source income to less than the tax rate on income from noncorporate investments.

If all investors are considered together, the corporate tax system does represent a double taxation of dividends and does on balance raise the effective tax rate on corporate-source income. But it is inappropriate for an analysis of the allocative effects of the tax to combine investors in this way if high- and low-income investors differ in their sensitivity to after-tax yields on corporate and noncorporate investments. If the high-income investors for whom the corporate tax system lowers the effective tax rate on corporate income are more responsive to the after-tax yield differential than the lower-income investors for whom the corporate tax system raises the effective tax rate, the net effect of the corporate income tax may be to increase the amount of capital used in the corporate sector.

This paper presents a portfolio model of the corporate income tax in an economy in which investors have different personal tax rates. The structure of the model is presented in the next section. Numerical simulations are presented in Section II. The final section com- 
ments briefly on the implications of this new model for the incidence and efficiency effects of the corporate income tax and suggests directions for extending the current analysis.

\section{A General Equilibrium Model with Portfolio Behavior}

The basic features of our problem can be represented by an economy with two classes of investors, a high-income group (denoted by a subscript $H$ ) and a low-income group (denoted by a subscript $L$ ). The low-income investors pay a personal tax rate of $t_{t}^{u}$. on investment income in unincorporated activities and an effective tax rate on corporate-source investment income (including both the corporate and personal income taxes) of $t_{t}^{c}$. For this group, we make the usual assumption that a corporate tax system implies $t_{L}^{c}>t_{L}^{u}$. For the high-income group, the corresponding tax rates are $t_{H}^{u}$ and $t_{H}^{c}$. We shall draw the line between "high" and "low" so that $t_{H}^{u}>t_{H}^{c}$, that is, so that the high-income group pays a lower effective tax rate on corporate income than on unincorporated income. ${ }^{2}$ In the next section we shall also consider the case in which $t_{H}^{u}<t_{H}^{c}$ but in which the additional corporate tax burden is relatively more important to the low-income group.

The unequal tax rates create an immediate problem for the traditional model of investor equilibrium. Harberger $(1959,1962,1966)$ and others have always assumed that the risk-adjusted after-tax yields on corporate and noncorporate investments were equal in equilibrium. With $t_{i .}^{c}>t_{L}^{u}$ and $t_{H}^{c}<t_{H}^{u}$, this equality of after-tax yields cannot be true for both classes of investors. To see this explicitly, let $F_{k}^{c}$ be the marginal product of capital in the corporate sector and $F_{k}^{u}$ be the marginal product of capital in the unincorporated sector. Let the corporate sector good be chosen as numeraire (so that its price is 1) while the price of the unincorporated sector's good is $p$. The after-tax return on corporate investment to investors in class $i$ is thus $\left(1-t_{i}^{c}\right) F_{k}^{c}$ while the corresponding after-tax return on unincorporated investment is $\left(1-t_{i}^{u}\right) p F_{k}^{u}$. Since $\left[\left(1-t_{H}^{c}\right) /\left(1-t_{H}^{u}\right)\right] \neq\left[\left(1-t_{f}^{c}\right) /\left(1-t_{L}^{u}\right)\right]$, it is clear that after-tax yields cannot be equal for both groups in both sectors.

If unequal after-tax yields are incompatible with equilibrium, both classes of investors cannot own both types of assets. To see this,

2 To see that this is possible with our actual tax rates, consider an individual with a marginal personal tax rate of 70 percent. This is his effective rate of tax on additional income from unincorporated investments. If he invests in a corporation that earns $\$ 100$ of taxable profit, the corporation pays $\$ 48$ of corporate income tax. If 40 percent of the remaining $\$ 52$ is paid as dividends, the individual pays an additional $0.7(\$ 20)=\$ 14$ of personal tax. His total tax is thus $\$ 62$, substantially lower than the personal tax rate. Even if the $\$ 30$ of retained earnings is subject to capital gains tax in the future, the present value of that tax is unlikely to be as large as the $\$ 8.00$ differential. 
consider what happens if the lower-income group does hold both types of assets, that is, if $\left(1-t_{L}^{c}\right) F_{k}^{c}=\left(1-t_{L}^{u}\right) p F_{k}^{u}$. Since $t_{L}^{c}>t_{L}^{u}$, this implies $F_{k}>p F_{k}^{u}$. The high-income investors will then hold only corporate investments because $F_{k}^{c}>p F_{k}^{u}$ and $t_{H}<t_{H}^{u}$ implies $\left(1-t_{H}^{c}\right) F_{k}^{c}$ $>\left(1-t_{H}^{u}\right) p F_{k}^{u}{ }^{3}$

Such specialization is not consistent with the observed ownership of corporate and noncorporate investments. High-income investors do make investments in real estate and other unincorporated businesses as well as in corporate equity. ${ }^{4}$ To reconcile observed asset ownership with the existence of unequal relative tax rates, it is necessary to replace the equal-net-yield model of equilibrium asset ownership with a more general portfolio balance description of this equilibrium.

In an economy in which both corporate and noncorporate investments have uncertain yields, individual investors will want to hold both assets in their portfolios." The relative quantities of both assets that an individual demands depend on their expected net-of-tax yields and on the net-of-tax risk structure of the assets. We shall not derive explicit portfolio choice equations from a basic model of utility maximization but will posit a constant-elasticity asset demand equation relating the fraction of his portfolio that an individual holds in each asset to the relative expected yields of the two assets and the relative standard deviations of those yields. We recognize that this equation, like the production functions and commodity demand equations of our model that are introduced below, is only a rough approximation of reality.

In this framework, we shall write $F_{k}^{k}$ and $F_{k}^{u}$ for the expected marginal products of the corporate and unincorporated sectors, respectively. ${ }^{6}$ We also write $\sigma_{c}$ and $\sigma_{u}$ for the pretax standard deviations of these returns. For the high-income investors, the after-tax expected returns are thus $\left(1-t_{H}^{c}\right) F_{k}^{c}$ and $\left(1-t_{H}^{u}\right) p F_{k}^{u}$, and the after-tax standard deviations of these returns are $\left(1-t_{H}^{t}\right) \sigma_{c}$ and $\left(1-t_{H}^{u}\right) \sigma_{u}$. If $\bar{K}_{H}$ denotes the total amount of capital owned by high-income individuals and $K_{H}^{r}$ the amount of that capital invested in the corporate sector, the constant-elasticity portfolio demand equation for highincome investors can be written

$$
\frac{K_{H}^{c}}{\bar{K}_{H}}=k_{H}\left[\frac{\left(1-t_{H}^{c}\right) F_{k}^{c}}{\left(1-t_{H}^{u}\right) p F_{k}^{u}}\right]^{\mu}\left[\frac{\left(1-t_{H}^{c}\right) \sigma_{c}}{\left(1-t_{H}^{u}\right) \sigma_{u}}\right]^{\eta_{H}}
$$
${ }^{3}$ Note that specialization does not require $t_{H}^{C}<t_{H}^{u}$ but only that $\left[\left(1-t_{H}^{c}\right) /\left(1-t_{H}^{U}\right)\right] \neq[(1$
$\left.\left.-t_{L}^{(}\right) /\left(1-t_{L}^{\nu}\right)\right]$.

"See, e.g., the evidence in Projector and Weiss (1966).

5 For a useful statement of basic portfolio theory in a model with two risky assets, see Tobin (1965). For analyses that deal explicitly with tax considerations in such a model, see Richter (1960), Feldstein (1969), and Stiglitz (1969). For a brief summary of this
theory and of more general contributions, see Feldstein (1976). Recall that the corporate good is numeraire in our model so that its price is
implicitly one. 
where $\mu_{H}>0$ and $\eta_{H} \leqslant 0$, and $k_{H}$ is the share of the capital of high-income individuals that would be invested in the corporate sector if the expected net yields and associated net risks were the same in both sectors. Changes in the sectoral allocation of capital and labor will change the expected marginal products of capital according to production-function conditions which we shall specify below. There is no obvious way to specify the determination of the relative pretax risk, $\sigma_{c} / \sigma_{u}$. It would not be unreasonable to assume that these standard deviations were independent of the respective means and that $\sigma_{c} / \sigma_{u}$ is therefore a constant. Alternatively, the relative pretax risks might remain constant, making $\sigma_{c} / \sigma_{u}$ proportional to $F_{k}^{c} / p F_{k}^{u}$. We specify a more general constant-elasticity relation which includes both possibilities as special cases:

$$
\frac{\sigma_{c}}{\sigma_{u}}=R\left(\frac{F_{k}^{c}}{p F_{k}^{u}}\right)^{\gamma}
$$

Substituting equation (2) into equation (1) yields

$$
\frac{K_{H}^{c}}{\bar{K}_{H}}=\lambda_{H}\left(\frac{F_{k}^{c}}{p F_{k}^{u}}\right)^{\mu_{H}+\gamma \eta_{H}}\left(\frac{1-t_{H}^{c}}{1-t_{H}^{u}}\right)^{\mu_{H}+\eta_{H}}
$$

where $\lambda_{H}=R^{\eta_{H}} k_{H}$, the share of the capital of high-income individuals that would be invested in the corporate sector if there were no taxes and the expected yields were equal. Note that in the special case of constant relative pretax risk $(\gamma=1)$, equation (3) implies that the demand for corporate capital depends only on the relative net-of-tax expected yields. ${ }^{\text {A }}$ similar equation describes the portfolio equilibrium of the low-income group.

These two portfolio balance equations can be embodied in a general equilibrium model that is a natural generalization of Harberger's 1962 analysis extended to an economy with two groups of capital owners. $^{8}$ We follow Harberger in specifying (1) a production function for each sector, (2) a labor market equilibrium condition that the marginal revenue product of labor must be equal in both sectors, and (3) a simple demand equation in which the relative demand for corporate and noncorporate goods depends on the relative price and not on the distribution of income. For each class of investors, there is a constraint that the total available capital must be divided exhaustively between the two sectors. For each sector, there is a constraint that the total capital used in production is the sum of the capital received from

' For evidence of the ability of this simple model to explain individual portfolio composition, see Feldstein (1976). We assume that $\mu_{i}+\eta_{i}>0$, i.e., that the expected net yield dominates the net risk as a determinant of portfolio allocation.

${ }^{\mathrm{a}}$ The full model is stated explicitly in NBER Working Paper no. 241-R, an earlier but more complete version of the current paper. 
the two classes of investors. Finally, a constraint that the total labor $(\bar{L})$ is divided between the corporate $\left(L^{c}\right)$ and noncorporate $\left(L^{u}\right)$ uses completes the model. These 11 equations determine the 11 endogenous variables: the outputs of the two sectors, the relative price of the two goods, and the allocation of labor and capital $\left(L^{c}, L^{u}, K^{c}, K^{u}, K_{H}^{c}\right.$, $\left.K_{H}^{u}, K_{L}^{c}, K_{L}^{u}\right)$. The exogenous variables of the model are the total labor supply $(\bar{L})$, the capital stocks of the two income classes $\left(\bar{K}_{H}\right.$ and $\left.\bar{K}_{L}\right)$, and the four tax rates.

In this more general model, substituting a corporate income tax system for the partnership method of taxing corporate-sector income can actually increase the share of total capital that is used in the corporate sector even though the average tax rate on corporate income is then higher than it would be if the same pattern of ownership were taxed by the partnership method. More formally, $K^{c} / K^{u}$ can rise when we replace a tax system in which $t_{L}^{c}=t_{L}^{u}$ and $t_{H}^{c}=t_{H}^{u}$ by one in which $t_{L}^{c}>t_{L}^{u}$ and $t_{H}^{c}<t_{H}^{u}$ even though $t_{L}^{c} K_{L}^{c}+t_{H}^{c} K_{H}^{c}>t_{L}^{u} K_{L}^{c}+t_{H}^{u} K_{H}^{c}$.

This "counterintuitive" result can occur if the capital that is withdrawn from the corporate sector by low-income investors (because $t_{L}^{c}$ $\left.>t_{L}^{u}\right)$ is less than the capital that is added by the high-income investors (because $t_{H}^{c}<t_{H}^{u}$ ). The likelihood of this occurring depends on the relative amounts of capital owned by each group $\left(\bar{K}_{L}\right.$ and $\left.\bar{K}_{H}\right)$, the differentials in the tax rates under the corporate tax system, and the relative asset demand elasticities of both groups (the $\mu_{i}$ 's and $\eta_{i}$ 's). Consider an obvious extreme case: If $\gamma=1$ and $\mu_{L}+\eta_{L}=0$ while $\mu_{H}+\eta_{H}>0$, the corporate capital stock would be increased by a corporate tax system since high-income investors would switch assets to the corporate sector while low-income investors would leave their portfolios unchanged. Such an extreme assumption is not necessary. The next section presents an explicit numerical calculation to show that this surprising effect of the corporate tax system is possible with more plausible parameter values. More generally, the analysis of the next section shows that, with more realistic parameter values, recognition of portfolio behavior does not reverse the usual direction of the capital flow but does substantially reduce its magnitude.

\section{Numerical Solutions of the Model for Alternative Tax Rules}

We have used a specific numerical version of the model presented in the previous section to calculate how the allocation of the nation's capital stock between the corporate and noncorporate sectors could change if the current corporate tax system were eliminated and the profits arising in corporate activities were instead taxed like ordinary 
income. The initial values of the model with the corporate income tax in place are a stylized characterization of the U.S. economy in 1973.

To create two classes of investors, we have drawn a dividing line at $\$ 50,000$ of adjusted gross income. With the help of a microeconomic simulation model which incorporates some 28,000 individual tax returns for 1973, we are able to calculate the average tax rates on additional corporate and noncorporate income for the high- and lowincome investors defined in this way. ${ }^{9}$

On the basis of Kendrick's (1976) recent estimates of national wealth, we take total privately owned capital in 1973 to be about $\$ 3.6$ trillion. Twenty-five percent, or $\$ 0.9$ trillion, we assign to the corporate sector. ${ }^{10}$ To divide the ownership of this capital between highand low-income investors, we have used the Federal Reserve Board Survey of Financial Characteristics of Consumers (Projector and Weiss 1966); although this survey is becoming dated, it remains the only source of such information. The survey showed that households with 1962 incomes over $\$ 25,000$ owned approximately 25 percent of total wealth and 45 percent of publicly traded corporate stock. Since per capita personal income in 1973 was 2.1 times the 1962 level, we use these proportions to describe the wealth holdings corresponding to the $\$ 50,000$ income level in 1973 . These approximations imply that the $\$ 3.6$ trillion capital stock is divided as follows: High-income investors own $\$ 405$ billion of corporate equity and $\$ 495$ billion of other assets while low-income investors own $\$ 495$ billion of corporate equity and $\$ 2,205$ billion of other assets. ${ }^{11}$

The production functions for the two sectors are specified to be Cobb-Douglas. The parameter values, based on the two-sector version of the recent analysis by Shoven (1976), ${ }^{12}$ have a capital coefficient of

\footnotetext{
${ }^{9}$ For a description of this TAxsIm computer model and its use with corporate-source income, see Feldstein and Frisch (1977).

${ }^{10}$ The flow-of-funds accounts list the market value of corporate equities in 1973 to be $\$ 911$ billion.

"Our analysis classifies corporate debt with "other assets" because the corporate income tax applies only to the equity component of corporate capital. We regard this as a crude approximation since we believe that debt and equity cannot be regarded as independent in this way. We also regard the Harberger-Shoven-Whalley assumption of a fixed debt-equity ratio as unsatisfactory. The problem of including corporate debt is compounded by the fact that much of the debt is held by funancial intermediaries and not by the individuals themselves. This analysis, in common with previous studies of the corporation tax, ignores the role of financial intermediaries. Because of the special tax rules applicable to banks and insurance companies, this indirect form of ownership cannot be treated as if it were the same as direct ownership by individuals. We reiterate that our current analysis is intended to illustrate the effect of the corporate tax system in a stylized economy and cannot accurately portray the U.S. economy,

${ }^{12}$ Shoven's table 2 presents his corrected version of Harberger's original data. By reallocating 45 percent of the corporate capital and labor (the approximate percentage not backed by equity) to the noncorporate sector, the new factor shares can be calculated. Our noncorporate sector, a mix of Shoven's corporate sector and highly capital-
} 
.207 in the corporate sector and .320 in the noncorporate sector. Our labor allocations are based in a similar fashion on the wage bills paid in 1973 by the corporate and noncorporate sectors; we have 253 billion units in the corporate sector and 263 billion units in the noncorporate sector. ${ }^{13}$ In specifying the demand function, we follow the original assumption of Harberger that the share of national income spent on corporate-sector goods is not affected by the relative price of these goods or by changes in the distribution of income. ${ }^{14}$

With realistic values of the tax rates and dividend payout ratios, the corporate tax system is not a "shelter" for the group that we refer to as high-income investors. Nevertheless, the simulation shows that disaggregating by income class and using a plausible portfolio response elasticity can substantially alter the conclusions of the traditional analysis. For this calculation, we assume an effective corporate tax rate of 0.491 ; this is the average ratio of corporate tax payments to real corporate profits (after adjusting inventory profits and capital consumption for inflation) for the period 1965-75.15 The ratio of dividends to real after-tax profits during the period 1956-75, 0.659, will be used as the dividend payout rate for the simulations.

The weighted-average marginal personal tax rate for individuals whose adjusted gross incomes exceeded $\$ 50,000$ in 1973 was 0.568 . For individuals with adjusted gross incomes below $\$ 50,000$, the weighted-average rate was 0.257 . We take these to be the two tax rates on distributed dividends and on income from unincorporated investments: $t_{L}^{u}=0.257$ and $t_{H}^{u}=0.568$. Finally, we assume that the effective tax rate on the capital gains resulting from retained earnings is one-fourth of the individual's ordinary marginal tax rate. ${ }^{16}$

With these assumptions, the overall tax rates on corporate-source income are $t_{H}^{c}=0.706$ for the high-income group and $t_{L}^{c}=\mathbf{0 . 5 8 8}$ for the low-income group. ${ }^{17}$ Note that both of these corporate income

intensive noncorporate sector, is thus less capital-intensive than Shoven's noncorporate sector.

${ }^{13}$ The corporate wage bill in 1973 was $\$ 460.6$ billion, the private noncorporate approximately $\$ 55.6$. Allocating 45 percent of the corporate wage bill to our noncorporate sector yields these numbers.

${ }^{14}$ Our other assumptions determine this share to be about 45 percent.

15 This makes no adjustment for the real gains that corporations accrue as inflation lowers the real value of their debt. Making such an adjustment would strengthen our conclusion by lowering the effective corporate tax rate. This would require an offsetting change in the effective tax rate on the debt income. These compensating changes are difficult to make within the framework of the current analysis. More generally, see Feldstein and Summers (1979).

${ }^{16}$ Recall that 50 percent of long-term capital gains are excluded in calculating taxable income and that the tax is collected only when (and if) the stock is sold. This implies that the effective capital gains rate is 0.142 for the high-income group and 0.064 for the low-income group.

17 The calculations are $0.491+0.509[0.659(0.568)+0.341(0.142)]=0.706$ for the high-income group and $0.491+0.509[0.659(0.257)+0.341(0.064)]=0.588$ for the low-income group. 
rates exceed the corresponding rates on unincorporated income: $t_{H}^{u}=$ 0.568 and $t_{L}^{u}=0.257$. Since the corporate tax system raises the tax rate on corporate-source income for both groups, there is an unambiguous shift of capital away from the corporate sector. The extent of this shift depends, however, on the nature of portfolio behavior. If we assume that the portfolio balance elasticities are both equal to $0.5,{ }^{18}$ the effect of integration would be to raise the corporate capital stock from $\$ 900$ billion to $\$ 1.045$ trillion, an increase of $\$ 145$ billion or 16 percent. The corporate capital stock of the high-income group increases by 10 percent while the corporate capital stock of the lowincome group rises by more than 20 percent.

These calculations differ significantly from the capital shift implied by the traditional two-sector model that aggregates all individuals and assumes an infinite elasticity of substitution between corporate and noncorporate assets in investors' portfolios. Combining the two classes of investors implies a weighted overall tax rate on unincorporated income of $t^{u}=0.397$ and a corresponding rate on corporate income of $t^{c}=0.641 . .^{19}$ With these tax rates and the requirement that the net-of-tax yields are equal now and would again be equalized after integration, the switch from the current rule to an integrated system would increase the corporate capital stock from $\$ 900$ billion to $\$ 1.291$ trillion. This is an increase of 43 percent, nearly three times as great as the shift implied by the disaggregated model.

With parameter values that are somewhat less realistic, our model can imply that integration actually reduces capital in the corporate sector. Consider an effective corporate tax rate of 0.40 , a dividend payout rate of 0.30 , and no effective tax on capital gains. With personal tax rates of $t_{L}^{u}=0.257$ and $t_{H}^{u}=0.568$, these assumptions imply total taxes on corporate-source income of $t_{L}^{c}=0.446$ and $t_{H}^{c}=0.502$. Since the relative tax rates on the two kinds of capital income are now reversed, the switch to an integrated tax will have the counterintuitive effect of reducing corporate capital if the portfolio balance response of the high-income group is sufficiently greater than the portfolio balance response of the low-income group (i.e., if $\mu_{H}+\eta_{H}$ is sufficiently greater than $\mu_{L}+\eta_{L}$ ).

A greater portfolio balance response for the high-income group

18 That is, $\eta_{H}+\mu_{H}=\eta_{L}+\mu_{L}=0.5$.

${ }^{19}$ Recall that the tax rates use a weighted average of personal marginal tax rates using dividends as the weights. Since the low-income group receives 55 percent of the dividends, the disaggregated rates $\left(t_{L}^{u}, t_{H}^{u}\right.$, etc. $)$ are combined in the $11: 9$ ratio. To insure that the equilibrium corporate capital stock under the current tax system is 900 billion, the share of national income spent on corporate goods was increased to 0.46 . Note that this implies a slightly different equilibrium allocation of labor than the one presented earlier (259 billion units in the corporate sector and 257 billion units in the noncorporate sector). 
seems plausible; their greater wealth provides a greater variety of investment opportunities and a greater incentive to be concerned about their investment strategies. With portfolio balance elasticities of $\eta_{H}+\mu_{H}=0.80$ for the high-income group and $\eta_{L}+\mu_{L}=0.29$ for the low-income group, a switch from the corporate tax system to an integrated system with equal tax yield has no effect on the total corporate capital stock. The corporate capital of the low-income investors rises from $\$ 495.0$ billion to $\$ 538.5$ billion while the corporate capital of the high-income group falls by an equal amount. With a smaller difference between the portfolio balance elasticities, the switch from the corporate tax system to the integrated system has the traditional effect of increasing the total corporate capital. With a greater difference between the price sensitivities, the switch in tax regimes has the counterintuitive effect of decreasing corporate-sector capital. $^{20}$

It is clear that the traditional view of the allocative effect of the corporate tax system deserves careful reconsideration. A central feature in any such analysis should be a model of portfolio behavior that goes beyond the conventional assumption of equal net yields. The disaggregation of investors by income class emphasizes the importance of such portfolio behavior and opens the possibility of differences in sensitivity among different income groups. Obviously, more empirical information on such portfolio behavior is needed to reach any valid conclusions about the actual effects of the corporate income tax system.

\section{Conclusion}

In this paper we have extended the traditional analysis of the corporate income tax to an economy with a progressive personal income tax. This extension implies a fundamental change in the analysis of the corporation tax itself. Analyzing such an economy requires replacing the traditional equilibrium condition that after-tax yields are equal on corporate and noncorporate investment with a more general portfolio balance requirement. ${ }^{21}$ Our analysis of this more realistic model shows that the introduction of a corporate income tax system could actually increase the fraction of the nation's capital stock that is used in the corporate sector even though the overall effective tax rate on corporate investment income is increased. Section II showed that this surprising result can occur even for quite feasible values of the

${ }^{20}$ See table I of our NBER Working Paper no. 24 I-R for specific numerical results.

${ }^{21}$ Note that this portfolio balance model is appropriate even if $t_{H}^{c}>t_{H}^{u}$ as long as the relative net yields cannot be equated, i.e., as long as $\left[\left(1-t_{H}^{c}\right) /\left(1-t_{H}^{u}\right)\right] \neq\left[\left(1-t_{L}^{c}\right) /(1-\right.$ $\left.\left.\iota_{L}^{u}\right)\right]$. 
portfolio balance behavioral elasticities. With parameter values that are a more realistic description of the current U.S. corporate tax system we showed that the more general disaggregated portfolio balance model implies a very substantial reduction in the extent to which the corporate tax system shifts the capital stock.

Our analysis has dealt with the effect of the corporate tax system on the allocation of the capital stock but not with the incidence of the corporate income tax. With the special assumptions of Section II that the technology is Cobb-Douglas in both sectors and that the shares of expenditure on the corporate and noncorporate goods are fixed, the form of the tax system does not affect the incidence of the tax: All of the tax is borne by capital. The Cobb-Douglas technologies and competitive markets imply that labor receives fixed shares of the value of each sector's product regardless of the tax system; the fixed shares of expenditure going to each sector then imply that labor receives a fixed fraction of total national income. With labor income fixed, capital must bear the cost of any resources collected by the government. This is exactly the same reasoning that applies to the Cobb-Douglas model in Harberger's 1962 paper; the disaggregation of capital ownership is irrelevant for this even when it affects the sectoral allocation of total capital. ${ }^{22}$ But if a more general technology or expenditure behavior is assumed, the distribution of income will generally depend on the form of the tax and the magnitudes of the portfolio balance elasticities.

Although we have not dealt explicitly with the efficiency aspects of the corporate income tax, the current paper implies that evaluating the excess burden of the corporate income tax should involve considerations that have previously been ignored. In the traditional analysis of the efficiency effects of the corporate income tax ${ }^{23}$ the welfare cost reflects the production inefficiency that results from the misallocation of capital between the corporate and noncorporate sectors. Since we have seen that the introduction of a corporate tax system can leave the allocation of total capital unchanged, it is important to stress that even in this case the corporate tax still does affect economic efficiency. Although there is no change in the production efficiency of the economy, there is a change in the way that risk is borne (i.e., in what we may call "portfolio efficiency"). Without an explicit theory of the optimal taxation of risky assets, it is not possible to say whether a move from equal tax rates on corporate and noncorporate investments (i.e., equal for any given taxpayer) to a system of

22 This defines incidence in the standard way, without any allowance for risk bearing.

${ }^{23}$ Harberger is again the pioneer in this analysis; see Harberger (1962). Shoven and Whalley (1972), Shoven (1976), and Feldstein (1978) present further developments within this framework. 
unequal tax rates causes a welfare gain or welfare loss. More generally, a full evaluation of the welfare loss (or gain) that results from the introduction of a corporate income tax requires assessing the effects on both production efficiency and portfolio efficiency. ${ }^{24}$

The present paper shows that quantifying the effects of the corporate income tax requires a better understanding of portfolio behavior than we currently have. First, the analysis of portfolio behavior should be extended to include the role and special tax treatment of financial intermediaries as well as of the portfolios held directly by individuals. Second, within this extended model we need reliable estimates of the basic portfolio balance elasticities. When this information is available, it will be possible to assess more accurately the likely effects of changes in corporate tax rules and to evaluate the welfare implications of those changes.

\section{References}

Feldstein, Martin S. "The Effects of Taxation on Risk Taking." J.P.E. 77, no. 5 (September/October 1969): 755-64.

- "Personal Taxation and Portfolio Composition: An Econometric Analysis." Econometrica 44, no. 4 (July 1976): 631-50.

- "The Welfare Cost of Capital Income Taxation."J.P.E. 86, no. 2, pt. 2 (April 1978): S29-S51.

Feldstein, Martin S., and Frisch, Daniel. "Corporate Tax Integration: The Estimated Effects on Capital Accumulation and Tax Distribution of Two Integration Proposals." Nat. Tax J. 30, no. 1 (March 1977): 37-52.

Feldstein, Martin S., and Summers, Lawrence. "Inflation and the Taxation of Capital Income in the Corporate Sector." Nat. Bur. Econ. Res. Working Paper no. 312, 1979. Nat. Tax J. 32, no. 4 (December 1979): 445-70.

Harberger, Arnold C. "The Corporation Income Tax: An Empirical Appraisal." In Tax Retision Compendium, House Committee on Ways and Means, 1959.

- "The Incidence of the Corporation Income Tax." J.P.E. 70, no. 3 (June 1962): 215-40.

- . "Efficiency Effects of Taxes on Income from Capital." In Effects of Comporation Income Trux, edited by Marian Krzyzaniak. Detroit: Wayne State Univ. Press, 1966.

Kendrick, John W., with Lee, Kyu Sik, and Lomask, Jean. The National Wealth of the United States, by Major Sector and Industry. New York: The Conference Board, 1976.

\footnotetext{
${ }^{24}$ The effect on capital accumulation must also be considered when the simplifying assumption of fixed capital stocks by income class is dropped. The earlier analysis of this source of welfare loss by Feldstein (1978) assumed a single class of investors and therefore that the corporate income tax, by raising the total tax rate on corporate income, distorted individuat choice by raising the relative cost of future consumption. The current paper shows that the corporate tax system may distort the choices of lowand high-income investors in opposite directions. It is again necessary to consider the disaggregated welfare losses since both groups may incur welfare burdens from this source even if the aggregate consumption pattern is unchanged.
} 
Projector, Dorothy S., and Weiss, Gertrude S. Survey of Financial Characteristics of Consumers. Washington: Fed. Reserve Tech. Papers, 1966.

Richter, Marcel K. "Cardinal Utility, Portfolio Selection, and Taxation." Rev. Econ. Studies 27, no. 74 (June 1960): 152-66.

Shoven, John B. "The Incidence and Efficiency Effects of Taxes on Income from Capital." J.P.E. 84, no. 6 (December 1976): 1261-83.

Shoven, John B., and Whalley, John. "A General Equilibrium Calculation of the Effects of Differential Taxation of Income from Capital in the U.S." J. Public Econ. 1, no. 3/4 (November 1972): 281-321.

Stiglitz, Joseph E. "The Effects of Income, Wealth, and Capital Gains Taxation on Risk-Taking." Q.J.E. 83, no. 2 (May 1969): 263-83.

Tobin, James. "The Theory of Portfolio Selection." In The Theory of Interest Rates, edited by F. H. Hahn and F. B. R. Brechling. London: Macmillan, 1965. 